\title{
Virgindade: tema atual, tema de História
}

História da virgindade.

KNIBIEHLER, Yvonne.

São Paulo: Editora Contexto, 2016. (trad. de Dilson Ferreira da Cruz do original La virginité féminine, mythes, fantasmes, émancipation. Paris: Odile Jacob, 2012.)

Quando certas questões ligadas ao universo feminino pareciam superadas no Brasil, eis que, como fantasmas do passado, elas ressurgem. Grupos políticos estimulados por visões religiosas fundamentalistas não só evitam que leis mais modernas sejam aprovadas no país, como ainda tentam promover retrocessos sociais no que diz respeito às relações de gênero. Além disso, num tempo em que persistem discriminações e violências contra as mulheres, vemos novas tecnologias e formas aprimoradas de comunicação sendo usadas também para agravá-las. E, finalmente, observamos com preocupação que a chegada de imigrantes (ainda que sempre desejada e bem-vinda) pode trazer consigo valores e hábitos retrógrados praticados em seus países de origem e contaminar conquistas feministas obtidas a duras penas em nossa sociedade.

Assim, a edição brasileira do livro História da Virgindade, de Yvonne Knibiehler, (Contexto, 2016) é mais do que necessária, uma vez que confere historicidade a questões como uso do corpo, condição feminina, direito das mulheres e representações de gênero. A autora é especialista em História das mulheres, maternidade, sexualidade, saúde. Leitores de língua portuguesa a conhecem por sua participação na obra História das Mulheres no Ocidente dirigida por Georges Duby e Michelle Perrot. Na França, ela contribuiu para os principais debates sobre os direitos das mulheres, ganhou condecorações importantes (Légion d'honneur, Ordre national Du Mérite), fundou o Centre d'Etudes Féminines de l'Université de Provence e publicou mais de uma quinzena de livros, vários traduzidos para outras línguas. Um dos segredos de seu sucesso é a escrita fluente e a capacidade de se comunicar para além dos muros acadêmicos.

Em História da Virgindade, Knibiehler justifica a escolha do tema por sua atualidade comprovada, entre outras coisas, pela existência de clínicas que reconstituem hímen, pela atuação espalhafatosa dos norte-americanos do movimento No Sex, pela exigência de um "certificado de virgindade" das noivas instituída nos meios muçulmanos na França, pela persistência de fantasias masculinas com relação à virgindade feminina, e pelo caráter de rito de passagem que a perda do hímen ainda tem para inúmeras garotas de hoje. A autora demonstra que a virgindade continua a manter um relevante papel simbólico, fazendo parte do tecido social mesmo nas culturas mais avançadas em termos de emancipação feminina e liberdade sexual.

A obra é dividida em cinco partes. A Primeira, explora o pensamento e a prática de gregos e romanos que conferiam um caráter político ao corpo feminino. As três deusas virgens (Atena, Artêmis e Héstia) representavam diferentes dimensões simbólicas da virgindade que serviam de modelos para os mortais e definiam rituais ligados à proteção da infância, do lar, da cidade, do "mundo civilizado". As meninas púberes encarnavam o "futuro da cidade", a possibilidade de continuação da sociedade, que era patriarcal e patrilinear; pertenciam ao pai a quem cabia oferecê-las como esposas para que dessem à luz novos cidadãos, a elite privilegiada. A situação concreta das meninas, o destino das filhas de não cidadãos e dos fetos também são examinados nessa parte do livro que termina com uma análise do saber médico na era hipocrática, quando a observação empírica do corpo 
humano já fazia parte do conhecimento construído a seu respeito, embora a ideologia da inferioridade feminina condicionasse todas as pesquisas e conclusões. Soranos e Galeno mudariam um pouco esse quadro, mas a grande novidade seria a difusão da doutrina cristã

Na Segunda parte da obra, Knibiehler apresenta as interpretações a respeito da virgindade que surgiram com as religiões monoteístas. Judeus a valorizavam, sobretudo, como forma de garantir a legitimidade da futura prole; assim, o controle da sexualidade feminina e sua "pureza" eram fundamentais. Para os antigos hebreus, homem e mulher tinham igual possibilidade de obter prazer nas relações carnais, a união de corpos não prejudicava a espiritualidade e o casal (e não apenas o homem) era valorizado. Contudo, na família e na sociedade, a dominção masculina acabou reforçada; no judaísmo, menstruação passou a ser sinal de impureza, a "defloração com sangue", um emblema, e as sucessivas gravidezes, uma obrigação da mulher casada. Com o cristianismo, a virgindade ganhou valor moral e espiritual, idealizada como um caminho para a santidade. Para as mulheres, a concepção cristã possibilitou a opção por uma existência independente de marido e filhos; ser "esposa de Cristo" podia significar maior autonomia e oportunidade de aprimoramento pessoal. A partir de então, e durante séculos, inspiradas por Maria, Agnes, Joana D'Arc e outras, muitas mulheres preservariam sua virgindade como forma de ganhar liberdade e usufruir de uma fonte de poder. Entre os muçulmanos, a virgindade feminina significaria a possibilidade máxima (só para os homens) de alcançar a satisfação sexual: no paraíso de Alá, o crente será servido pelas huris, belas jovens virgens. Mais importante que a autenticidade da filiação é "ser o primeiro", se possível de várias - o que reforça a posição dominante do homem.

O apogeu da virgindade feminina - tema da Terceira parte - ocorreu na cristandade ocidental durante a Idade Média e a Era Moderna. Ser "donzela" conferia status - assim mostram os contos populares, as hagiografias, os escritos teológicos, a devoção à Imaculada Concepção e a opção pelo claustro, os votos, - véu. Por outro lado, a violação passou a provocar maior excitação ao ressaltar, em termos de representações, a virilidade do sexo forte. A agressão, que atentava contra a honra de todos da família, especialmente pai e irmãos, era então uma questão para ser resolvida entre homens, frequentemente com sangue. A vítima por sua vez, acabava marginalizada, ganhando alguma simpatia social apenas a partir do século $\mathrm{XVII}$. Enquanto isso, a medicina avançava no conhecimento do corpo e no reconhecimento do hímen, permitindo que os sinais da virgindade fossem "identificados".

Manter as jovens "puras" até o casamento tornou-se algo mais problemático com o aumento da idade ao casar propiciado pela Revolução demográfica. Caberia a elas a responsabilidade moral na preservação de sua virgindade e, consequentemente, maior culpa em caso de perda antes do matrimônio. Contra os riscos da sedução tínhamos agora a "educação virginal" (além da constante vigilância social), a ênfase na "modéstia", o "exame de consciência". Foi assim, conta Knibiehler, que surgiu a "moça". Entretanto, em um contexto em que o pátrio poder e a dominação masculina prevaleciam, temos algo inusitado: o amor romântico (humano) como decorrência da crença, mais antiga, na felicidade propiciada pelo êxtase místico (o amor divino).

O processo de dessacralização da virgindade - assunto da Quarta parte - iniciou-se com - lluminismo, e avançou graças ao desenvolvimento científico, à laicização da sociedade e à emancipação feminina. $O$ corpo humano passa a ser naturalizado e secularizado. No início do século XIX, a existência do hímen não era mais contestada (no futuro, os favoráveis à liberdade sexual descartarão sua importância, enquanto os que a temem, procurarão proteger a membrana a qualquer custo). A autoridade da ciência se impôs no imaginário social e passou a estabelecer regras de vida, inspirando uma "moral higiênica". A seus olhos, a saúde da moça (futura esposa e mãe) adquiriu um valor político capaz de afetar a "riqueza das nações". Na Revolução Francesa, as moças ganharam maior liberdade, mas logo veio a reação: reforço da cultura patriarcal, educação para a docilidade, a domesticidade e a inocência (ignorância sexual) em detrimento da instrução formal, reforço legal da ideia de que a jovem deflorada é a única culpada. Nessa época, a virgindade feminina retomou seu brilho tanto porque muitas mulheres continuaram celebrando-a (multiplicação da profissão religiosa e das devoções populares) quanto porque os homens a viam como uma garantia de fidelidade e submissão feminina. Aumentou, porém, a distância entre os cônjuges e a dupla moral sexual que, entre outras coisas, fez crescer até a discriminação de classe.

A partir do final do século XIX, o individualismo, o declínio das vocações religiosas, as mudanças nas representaçốes do feminino, a valorização da instrução secular e o feminismo - 
com suas bandeiras de educação sexual e igualdade entre os sexos - aceleraram a desimportância da virgindade. As alterações comportamentais do pós-Primeira Guerra Mundial foram acentuadas com a popularização da psicanálise, que deu destaque à sexualidade na vida humana e à diversidade de desejos e experiências. No pósSegunda Guerra, o ritmo aumentou com a difusão de práticas contraceptivas nas mãos das mulheres, a escola mista, o crescimento do número de médicas e das pesquisas sobre sexualidade. As referências ao sexo, a valorização do desejo e as descrições do ato sexual ficaram cada vez mais banais na imprensa, no cinema, na literatura e nas salas de aula. Knibiehler lembra também o impacto social da pílula anticoncepcional e da Revolução Sexual do final dos anos 1960 na liberação feminina, no planejamento familiar e no desprestígio do hímen e da vergonha associada ao corpo. O estupro finalmente passou a ser condenado por seu caráter violento e não mais por questões morais ou de honra familiar.

Knibiehler conclui com as inquietações de uma era em que a virgindade feminina parece não ter mais nenhum valor (será?). Sua função como garantia de legitimidade da prole se extinguiu com os avanços científicos no controle da natalidade e nos testes de DNA. Sua função de conferir status e autonomia ao "sexo fraco" perdeu a razão de ser com a emancipação feminina. E a de assegurar a dominação masculina na união conjugal diminul muito com a liberação sexual e o declínio do patriarcado. Contudo, a autora questiona se é mesmo o caso de declarar o fim da desigualdade de gênero ou o triunfo da sexualidade livre quando se observa a prática cotidiana.

Na Quinta e mais francesa das partes do livro, Knibiehler propõe uma reflexão a respeito do real grau de desqualificação social da virgindade feminina, já que o assunto não morreu. $O$ fato de apresentar uma realidade francesa não deve desinteressar o leitor brasileiro. Podemos aprender muito observando uma sociedade na qual o pensamento laico é poderoso, os mulçumanos são influentes, o aborto é legal, e as pesquisas sobre as práticas sexuais são bem desenvolvidas. Estabelecer comparações com o nosso país é o próximo passo.

Embora as jovens possam dispor de sua virgindade, a liberdade sexual e a valorização das escolhas pessoais trazem consigo novos problemas. Deixar de ser virgem é ainda no século XXI um rito, triunfal ou angustiante. Diante da grande variedade de experiências, levando a crer que a subjetividade pesa hoje muito mais do que antes, Knibiehler confronta dados gerais (como a média de idade na primeira relação sexual) com testemunhos pessoais que confirmam a pressão masculina e familiar interferindo nas "escolhas", a submissão às prescrições médicas, os efeitos colaterais dos contraceptivos, as dificuldades em reportar um estupro, e os riscos (como a gravidez indesejada). Além disso, certos grupos religiosos fazem releituras da virgindade, colocando-a num pedestal, abominando as não virgens e, como efeito colateral, fazendo proliferar na França os atestados médicos de virgindade e as cirurgias de reconstituição de hímen...

Nada como uma História bem feita para iluminar presente e futuro.

[Recebida em 16/03/2016 e aceita para publicaão em 25/04/2016]

Carla Bassanezi Pinsky Editora Contexto, São Paulo, Brasil 